\title{
Effectiveness of Fiscal Policies in Controlling Inflation in Indonesia with the Seemingly Unrelated Regression Model
}

\author{
Lia Nazliana Nasution ${ }^{1}$, Ade Novalina ${ }^{2}$, Dede Ruslan ${ }^{3}$ \\ $\left\{\underline{\text { lianazliana@dosen.pancabudi.ac.id }{ }^{1 *}}, \underline{\text { adenovalina@gmail.com }}{ }^{2}, \underline{\text { dras ruslan@yahoo.com }}{ }^{3}\right\}$ \\ ${ }^{1,2}$ Doctoral Students in Economics Universitas Sumatera Utara \\ ${ }^{3}$ Economics Lecturer Universitas Negeri Medan \\ ${ }^{1,2}$ Economics Lecturers, Universitas Pembangunan Panca Budi \\ *lianazliana@dosen.pancabudi.ac.id
}

\begin{abstract}
The purpose of this study is to see how effective fiscal policy in controlling inflation in Indonesia. The fiscal policy variables used are tax revenue, government spending, and foreign direct investment (FDI). The data used are secondary data types ranging from 1982 to 2018. Based on the results of research using the Seemingly Unrelated Regression (SUR) model, shows that fiscal policy variables measured through tax revenues, FDI, and government spending have a significant effect on the development of the inflation in Indonesia. Tax revenue is having a substantial impact on government spending. Likewise, FDI has a significant impact on the money supply in Indonesia during the observation
\end{abstract}

Keywords: Fiscal Policy, Inflation, Indonesia

\section{Introduction}

In a country like Indonesia, there is very often turmoil in maintaining the stability of economic activity. The economy in Indonesia has always been an essential thing because if the economy is in an unstable condition, financial problems will arise, such as low economic growth, high unemployment, and high inflation, and the decline in the value of the rupiah. Many people feel that the prices of goods and services for necessities today are higher than the costs of these goods and services one or two years ago.

Inflation is an economic problem that cannot be ignored because increases can have a far-reaching impact. Therefore inflation is the main target in government policy. The high rise is significant to note because of its effects on the economy, which can lead to instability, slowing economic growth, unemployment, which is always increasing, and the declining value of the currency. 


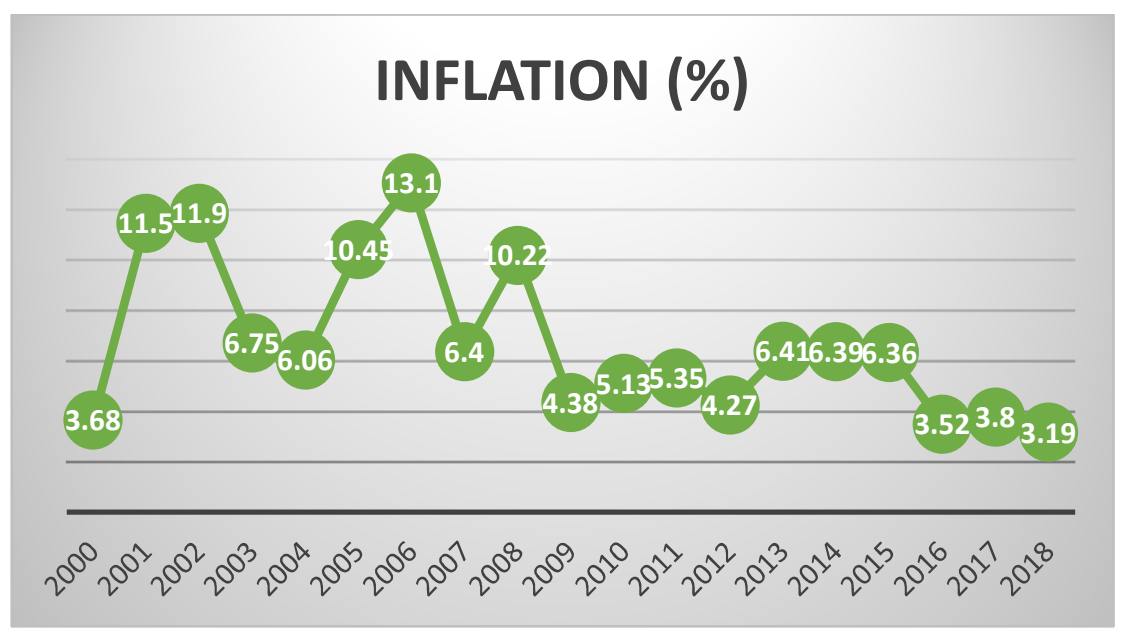

Source: World Bank[1]

Fig 1. Inflation in Indonesia, Year $2000-2018$

Figure 1 above shows the inflation growth data in Indonesia, which were active from 2000 to 2018. From 2000 to 2008, the inflation rate in Indonesia experienced a sharp increase and decrease. The highest inflation occurred in 2006, amounting to $13.1 \%$. The cause of the high inflation rate is less conducive to domestic security triggered by government policies that raise fuel prices, electricity, and telephone tariffs [2]. From 2009 to 2018, inflation in Indonesia is still fluctuating, but the increase or decrease is not so sharp. The lowest inflation occurred in 2018 at $3.19 \%$.

In inflation targeting, the monetary policy framework is implemented with an approach based on the price of commercial quantities. However, the value of inflation that occurs is often not following the predetermined target. It is influenced by policies carried out, both in the monetary and fiscal fields. This research was conducted specifically to see how effective fiscal policy is in controlling inflation in Indonesia with the SUR model approach.

\section{Inflation}

In economic theory, the definition of inflation, "Inflation occurs when the general level of prices is rising," or in other words, inflation occurs when the level of prices, in general, continues to increase [3]. It does not mean that the costs of various types of goods go up by the same percentage. The important thing is that there is a general increase in the price of goods continuously for a specified period.

An economy is said to have experienced inflation if the following three characteristics are met, namely: 1) an increase in prices, 2) a general increase in prices, and 3) continue continuously. Several indicators can be used to determine whether an economy is hit by inflation or not [4]. These indicators include:

a. Consumer Price Index (CPI)

CPI is the price index most commonly used as an indicator of inflation. The CPI presents the price of goods and services consumed by the public in a certain period.

b. Wholesale Price Index (IHPB)

It is an indicator that describes the price movements of commodities traded at the producer level in a particular area in a certain period. If the CPI observed is the final goods 
consumed by the public, the CPI found is raw goods and intermediate goods, which are input for producers.

c. GDP Deflator

The deflator is comparing the level of nominal economic growth with real growth.

To measure the rate of increase in the level of general prices or inflation, the following general formula used:

$$
\mathrm{I}_{\mathrm{t}}=\frac{H U t-H U t-1}{H U t-1}
$$

Where:

$\begin{array}{ll}\text { It } & : \text { Inflation rate in a period (or year) } \\ \text { HUt } & : \text { The actual prevailing price in the period t } \\ \text { HUt-1 } & : \text { The actual general cost in the period } t-1 .\end{array}$

The wholesale trade index measures the rate of inflation using many goods at the level of large traders. Thus the calculation includes the price of raw materials, prices of raw materials, and prices of finished goods. Measuring inflation with the GDP deflator is by calculating the value of goods and services included in the calculation of net national income. The formula for calculating GDP deflator is:

$$
\text { GDP Deflator }=\frac{\text { GNPNominal }}{\text { GNPRill }} \times 100
$$

\section{Fiscal Policy}

Fiscal policy is the use of government spending and taxation in influencing the economy. When the government decides to purchase goods and services, payment of shared transfers, or tax collection, the government is involved in fiscal policy [5]. Fiscal policy can also change aggregate demand. The ability of fiscal policy to influence output by influencing aggregate demand makes it a potential tool for economic stabilization.

During a recession, the government can carry out an expansive fiscal policy, so that output can return to normal levels and make unemployed workers back to work. When inflation occurs, the government can run a surplus budget so that it helps slow down the economy.

\section{Relationship of Government Spending on Inflation}

According to Keynes, if the government implements a comprehensive fiscal policy, namely by increasing government spending, it will encourage price increases or will trigger inflation. In other words, an increase in government spending through expansionary fiscal policy will promote the economy of the real sector to grow. The productivity of the economy will then have an impact both on increasing demand for production input goods and consumer goods, thereby raising the price level.

\section{Relationship of Money Supply on Inflation}

The quantity theory of money is a theory which states that there is a direct relationship between changes in the money supply and changes in the price of goods. The connection noted that the amount of products is directly proportional to the money supply $(\mathrm{MV}=\mathrm{PT})$. In the majority, the inflation rate influenced by the money supply. Increasing the money supply in the community tends to increase consumption through spending. It will cause price increases due to increased demand from the public, and over time this will trigger inflation. 


\section{Research Method}

The model used in this study is Seemingly Unrelated Regression (SUR), with quantitative material using secondary data over 37 years, from 1982 to 2018. Arnold Zellner introduced the Seemingly Unrelated Regression (SUR) Model in 1962. Zellner stated that SUR is a multivariate regression model (multiple regression), and is part of multiple linear regression. SUR is a model that consists of several equations, and the variables are not bidirectional. Still, between these equations, there is a correlation between these commonality errors known as peer correlations. The SUR model consists of several unrelated equation systems, meaning that each variable (dependent and independent) exists in one order.

SUR Model Equations:

$$
\begin{gathered}
\text { Inf }=a_{10}+b_{11} \operatorname{LogTax}+b_{12} \operatorname{LogGov}+e_{1} \\
\text { Inf }=a_{20}+b_{21} \operatorname{LogFDI}+b_{22} \operatorname{LogJUB}+e_{2} \\
\text { Inf }=a_{30}+b_{31} \operatorname{LogTax}+b_{32} \operatorname{LogFDI}+e_{3} \\
\text { LogGov }=a_{40}+b_{41} \operatorname{LogTax}+e_{4} \\
\text { LogJUB }=a_{50}+b_{51} \operatorname{LogFDI}+e_{5}
\end{gathered}
$$

Where :

$\begin{array}{lll}\text { Inf } & = & \text { Inflation }(\%) \\ \text { Tax } & = & \text { Tax revenue } \\ \text { Gov } & = & \text { Government final consumption expenditure } \\ \text { FDI } & = & \text { Foreign Direct Investment } \\ \text { JUB } & = & \text { Money Supply } \\ \mathrm{a} & = & \text { Constant } \\ \mathrm{b} & = & \text { Coefficient } \\ \mathrm{e} & = & \text { Error term }\end{array}$

\section{Results and Discussion}

One of the problems that often occur in developing countries such as Indonesia is maintaining stability and economic growth. Economic security is related to the balance of the price level, national income, and increase in employment opportunities [6]. The series of policies can be carried out by the government to stabilize the economy; one of them is through fiscal policy.

The following are data on tax growth rates, FDI, government expenditures, and the money supply in Indonesia for the period 1983 to 2018. 


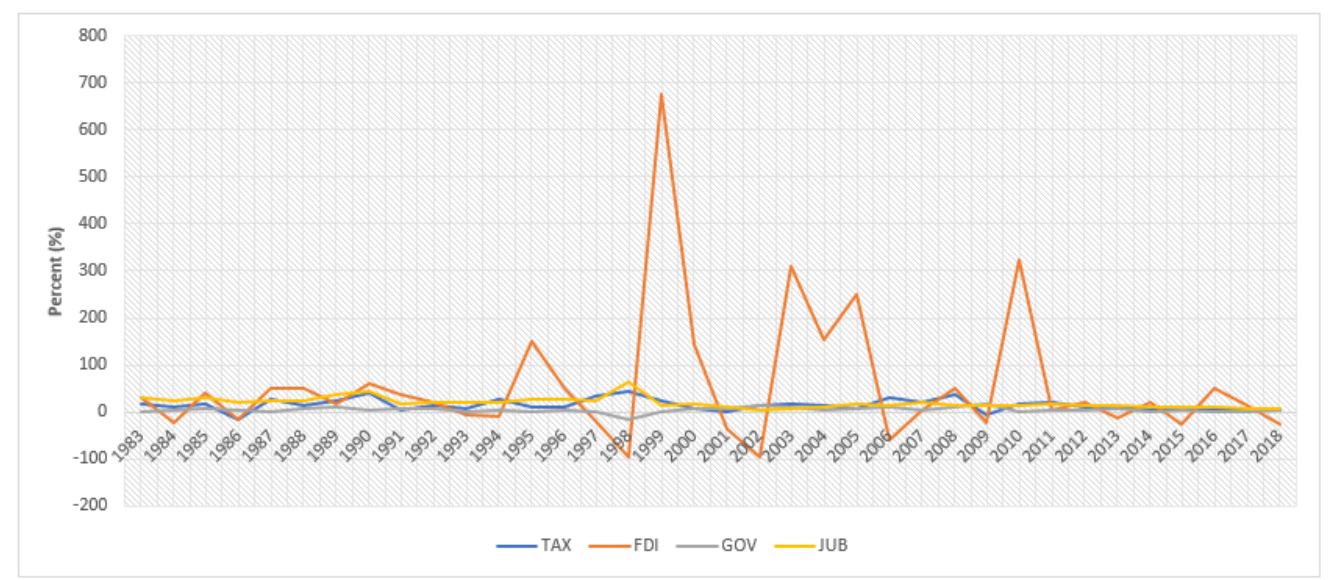

Source: World Bank [1]

Fig 2. Growth Rate of Tax Revenue, FDI, Government Expenditures, and Money Supply in Indonesia, Year $1983-2018(\%)$

Based on Figure 2 above, for 36 years, from 1983 to 2018, visible developments in the FDI rate fluctuate quite sharply. The highest FDI growth rate in 1999 reached up to $700 \%$, while the lowest growth rate in 1998 reached up to $-100 \%$. The rate of tax growth, government expenditure, and the money supply have been relatively stable for 36 years. The highest tax growth rate in 1990 was $40 \%$, and the lowest in 1986 was $-15 \%$. The highest growth rate of government expenditure in 2009 was $15 \%$, and the lowest in 1998 was $-15 \%$. The highest growth rate of the money supply was in 1998 at $62 \%$ and the lowest in 2002 at $4 \%$.

To find out the estimation using the SUR model, the results of processing using Eviews are as follows:

Table 1. SUR Estimation Results

\begin{tabular}{|c|c|c|c|c|}
\hline & Coefficient & Std. Error & $\mathrm{t}$-Statistic & Prob. \\
\hline$C(1)$ & 726.1576 & 77.71881 & 9.343396 & 0.0000 \\
\hline$C(2)$ & 6.464256 & 0.994419 & 6.500535 & 0.0000 \\
\hline$C(3)$ & -27.66206 & 3.074142 & -8.998303 & 0.0000 \\
\hline$C(4)$ & 38.89372 & 13.21035 & 2.944186 & 0.0037 \\
\hline $\mathrm{C}(5)$ & -3.037734 & 0.537377 & -5.652896 & 0.0000 \\
\hline$C(6)$ & 1.050919 & 0.294655 & 3.566603 & 0.0005 \\
\hline$C(7)$ & 41.44808 & 14.08406 & 2.942907 & 0.0037 \\
\hline $\mathrm{C}(8)$ & 0.627772 & 0.368588 & 1.70318 & 0.0903 \\
\hline $\mathrm{C}(9)$ & -2.460419 & 0.53488 & -4.599943 & 0.0000 \\
\hline $\mathrm{C}(10)$ & 23.41059 & 0.414093 & 56.53461 & 0.0000 \\
\hline $\mathrm{C}(11)$ & 0.310485 & 0.012663 & 24.51993 & 0.0000 \\
\hline$C(12)$ & 10.65134 & 2.560495 & 4.159873 & 0.0001 \\
\hline $\mathrm{C}(13)$ & 1.075776 & 0.119117 & 9.03128 & 0.0000 \\
\hline
\end{tabular}




\begin{tabular}{lc}
\hline \multicolumn{1}{c}{ Equation: } & R-squared \\
\hline$I N F=C(1)+C(2) * L O G T A X+C(3) * L O G G O V$ & 0.277795 \\
$I N F=C(4)+C(5) * L O G F D I+C(6) * L O G J U B$ & 0.212129 \\
$I N F=C(7)+C(8) * L O G T A X+C(9) * L O G F D I$ & 0.170127 \\
$L O G G O V=C(10)+C(11) * L O G T A X$ & 0.910375 \\
LOGJUB=C(12)+C(13)*LOGFDI & 0.635032 \\
\hline
\end{tabular}

\subsection{Equation 1 (Inflation)}

Based on the SUR estimation results in Table 1 above, the first equation formed is:

$$
\text { Inf }=726.1576+6.464256 \operatorname{LogTax}-27.66206 \operatorname{LogGov}+e_{1}
$$

Equation 8 shows that tax revenue has a positive and significant effect on inflation in Indonesia, with a coefficient of 6.464256 and a probability of $0.0000<\alpha=0.05$. It means that if tax revenue increases by $1 \%$, it will increase inflation by $6.464256 \%$.

While the variable government expenditure has a negative and significant effect on inflation in Indonesia with a coefficient of -27.66206 and a probability of $0.0000<\alpha=0.05$. It means that if government spending rises by $1 \%$, it will reduce inflation by $27.66206 \%$.

The coefficient of determination of equation 8 , as shown in Table 1 , is 0.277795 , which means that together tax revenues and government spending can explain inflation by $27.78 \%$, and the remaining $72.22 \%$ is explained by other variables not included in the estimation model.

\subsection{Equation 2 (Inflation)}

Based on the SUR estimation results in Table 1 above, the second equation formed is:

$$
\operatorname{Inf}=38.89372-3.037734 \operatorname{LogFDI}+1.050919 \log J U B+e_{2}
$$

Equation 9 shows that FDI has a negative and significant effect on inflation in Indonesia with a coefficient of -3.037734 and a probability of $0.0000<\alpha=0.05$. It means that if foreign direct investment increases by $1 \%$, it will reduce inflation by $3.037734 \%$.

The money supply has a positive and significant effect on inflation in Indonesia, with a coefficient of 1.050919 and a probability of $0.0005<\alpha=0.05$. It means that if the money supply rises by $1 \%$, it will raise inflation by $1,050919 \%$.

The coefficient of determination of equation 9, as shown in Table 1 , is 0.212129 , which means that together, the FDI and the money supply can explain inflation by $21.21 \%$, and other variables outside the estimation model explain the remaining $78.79 \%$.

\subsection{Equation 3 (Inflation)}

Based on the SUR estimation results in Table 1 above, the third equation formed is:

$$
\operatorname{Inf}=41.44808+0.627772 \log T a x-2.460419 \log F D I+e_{3}
$$


Equation 10 shows that tax income has no significant positive effect on inflation in Indonesia with a coefficient of 0.627772 and a probability of $0.0903>\alpha=0.05$. While the FDI variable has a negative and significant effect on inflation in Indonesia with a coefficient of -2.460419 and a probability of $0.0000<\alpha=0.05$. It means that if foreign direct investment rises by $1 \%$, it will reduce inflation by $2,460419 \%$.

The coefficient of determination of equation 10, as shown in Table 1, is 0.170127 , which means that together tax and FDI income can explain inflation by $17.01 \%$, and other variables outside the estimation model tell the remaining $82.99 \%$.

\subsection{Equation 4 (Government Expenditures)}

Based on the SUR estimation results in Table 1 above, the fourth equation formed is:

$$
\operatorname{LogGov}=23.41059+0.310485 \operatorname{LogTax}+e_{4}
$$

Equation 11 shows that tax revenue has a positive and significant effect on government spending in Indonesia with a coefficient of 0.310485 and a probability of $0.0000<\alpha=0.05$. It means that if tax revenue rises by $1 \%$, it will increase government spending by $0.310485 \%$.

The coefficient of determination of equation 11, as shown in Table 1, is 0.910375 , which means that tax revenue can explain other variables outside the estimation model explain government expenditure of $91.04 \%$ and the remaining $8.96 \%$.

\subsection{Equation 5 (Money Supply)}

Based on the SUR estimation results in Table 1 above, the fifth equation formed is:

$$
\operatorname{LogJUB}=10.65134+1.075776 \log F D I+e_{5}
$$

From equation 12 shows that foreign direct investment has a positive and significant effect on the money supply in Indonesia with a coefficient of 1.075776 and a probability of $0.0000<\alpha=0.05$. It means that if foreign direct investment rises by $1 \%$, it will increase the money supply by $0.310485 \%$.

The coefficient of determination of equation 12, as shown in Table 1, is 0.635032 , which means that FDI can explain other variables outside the estimation model explain the money supply of $63.50 \%$ and the remaining $36.5 \%$.

\section{Conclusion}

From the results of the research described above, it can see those tax revenues, FDI, and government spending have a significant effect on inflation in Indonesia during the 37 years of the observation period, from 1982 to 2018 . It means that fiscal policy variables are quite effective in controlling inflation in Indonesia. The money supply also influences inflation positively and significantly. According to the theory, if the money supply in the community increases, inflation will trigger.

Tax revenue has a positive and significant effect on government spending. It means that when tax revenue increases, government spending also increases. Because taxes are the largest source of government revenue in Indonesia, government spending on development, and others 
can also increase. FDI has a positive and significant effect on the money supply. When cash inflows increase, the money supply also increases, which can eventually lead to inflation.

\section{References}

[1] https://data.worldbank.org/country/indonesia

[2] https://www.bps.go.id/

[3] Samuelson, A., P. \& Nordhaus, D., W. Makro Ekonomi $14^{\text {th }}$ ed. Jakarta: Erlangga (2011).

[4] Manurung, M. \& Rahardja, P. Uang, Perbankan, dan Ekonomi Moneter (Kajian Kontekstual Indonesia). Jakarta: Lembaga Penerbit FEUI (2004).

[5] Weil, N., D. Fiscal Policy. Econlib, Featured Encyclopedia Entry (2011).

[6] Watulingas, J., Rotinsulu, O., T., \& Siwu, Dj., F., H. Pengaruh Aspek Moneter dan Fiskal Terhadap Inflasi di Indonesia. Jurnal Berkala Ilmiah Efisiensi. 16(01), 718 - 727 (2016). 